\title{
SCREENING FOR CELIAC DISEASE AMONG PATIENTS WITH TURNER SYNDROME IN BRASÍLIA, DF, MIDWEST REGION OF BRAZIL
}

\author{
Maria do Carmo Sorci DIAS', Luiz Claudio Gonçalves de CASTRO², Lenora GANDOLFI ${ }^{3}$, \\ Rodrigo Coutinho de ALMEIDA ${ }^{3}$, Mara Santos CÓRDOBA ${ }^{4}$ and Riccardo PRATESI ${ }^{3}$
}

\begin{abstract}
Context - Several studies have demonstrated a higher prevalence of celiac disease (CD) among females with Turner syndrome when compared to the general population. Nevertheless, there is no record in literature concerning this investigation among Brazilian patients. Objective - To assess the prevalence of CD among a group of Brazilian patients with Turner syndrome. Methods - Fifty-six females with Turner syndrome and on gluten-containing diet were screened for CD utilizing immunoglobulin A antiendomysium (IgA-EMA) and immunoglobulin A anti-tissue transglutaminase (IgA-tTG) antibody assays. Additionally, they were genotyped for CD human leukocyte antigen (CD-HLA) predisposing alleles. Patients showing positivity in serological testing were offered to perform small intestine biopsy for histological confirmation. Results - Mean age at diagnosis of Turner syndrome was $5.5 \pm 4.4$ years; mean age at screening for $\mathrm{CD}$ was $17.0 \pm 9.3$ years (from 10 months of age to 52 years). Two girls were positive for IgA-EMA and IgA-tTG, presented predisposing HLA-DQ2 alleles and both had the diagnosis of CD confirmed by jejunal biopsy. Conclusion - The 3.6\% prevalence of biopsy-proven $\mathrm{CD}$ among this group of females with Turner syndrome is 10 times higher than the one among females from the general population of the same geographical area. This result provides additional support to an association between these two disorders and restates that girls and women with Turner syndrome represent a high risk population for developing CD.
\end{abstract}

HEADINGS - Triage. Celiac disease. Turner syndrome. Autoimmunity. Antibodies.

\section{INTRODUCTION}

Turner syndrome (TS) is a genetic disease affecting females and resulting from the absence of the entire or just part of one chromosome $\mathrm{X}$, leading to a wide spectrum of phenotypic and clinical features, being the most prevalent short stature and premature ovarian failure ${ }^{(2,5,32)}$. It is one of the most common chromosomal abnormalities, with prevalence of $1: 2,500$ to $1: 3,000$ among live-born girls ${ }^{(30,31)}$.

Several studies have demonstrated the frequent association between TS and autoimmune disorders, being Hashimoto thyroiditis the most common, with a prevalence of approximately $20 \%{ }^{(15)}$. Other less frequently reported autoimmune disorders include inflammatory bowel disease ${ }^{(9,17)}$ and idiopathic juvenile $\operatorname{arthritis}^{(33,34)}$.

Since the last decade, an increasing number of studies have also demonstrated a higher prevalence of celiac disease (CD) among females with TS when compared with the general population ${ }^{(4,10,12,13,21)}$.
$\mathrm{CD}$ is a chronic gluten-sensitive enteropathy of autoimmune nature characterized by villous atrophy and crypt hyperplasia of the small bowel mucosa. CD shows a strong genetic predisposition that is strongly associated with the presence of human leukocyte antigen (HLA) class $\mathrm{II}^{(16,22,27)}$. Approximately $95 \%$ of cases show a particular DQ2 $\alpha / \beta$ heterodimer encoded by DQA $1 * 0501$ and DQB $1 * 0201$ alleles $^{(29)}$. Almost all the remaining DQ2-negative patients disclose the DR4-DQ8 haplotype. The presence of predisposing HLA alleles explains only in part the genetic susceptibility to $\mathrm{CD}^{(14)}$. In most European populations the frequency of DQ2 heterodimer is as high as $15 \%$ to $30 \%$, but only a minority of DQ2 positive subjects will develop CD. Although genetic linkage analyses have identified susceptibility loci on various chromosomes, the search for non-HLA genes of predisposition to the gluten enteropathy has been inconclusive so far ${ }^{(7,28)}$.

Although the association between CD and TS is an evidenced based fact, there is not records in

Institution: Celiac Disease Investigation Laboratory, Department of Pediatrics, University of Brasilia School of Medicine, Brasilia, DF, Brazi . All the authors declare that there is no conflict of interest concerning this research.

1 University of Brasilia School of Medicine; ${ }^{2}$ Pediatric Endocrinology Unit, University of Brasilia School of Medicine; ${ }^{3}$ Celiac Disease Investigation Laboratory, University of Brasilia School of Medicine; ${ }^{4}$ Department of Genetics and Morphology, Institute of Biological Sciences, University of Brasilia, DF, Brazil.

Correspondence: Dr. Luiz Claudio Gonçalves de Castro - SHIS QI 11 - Bloco S - sala 106 - 71640-215 - Brasilia, DF, Brazil. E-mail: Ic-castro@uol.com.br 
the literature concerning this prevalence investigation in Brazil. So the aim of this study was to assess the prevalence of CD among a group of Brazilian females with TS living in Brasilia, DF, Midwest region of the country.

\section{METHODS}

This study was approved by the Research Ethics Committee of the University of Brasilia School of Medicine (protocol 051/2003, September 8, 2003) and an informed consent was obtained from all adult patients and from parents of the children included in this survey.

This is a transversal study, in which females with TS confirmed by cytogenetic testing followed at the Clinical Genetic Unit of Brasilia University Hospital were invited to participate in this study. Fifty-six subjects accepted to be enrolled in, among them including the parents' acceptance in case of pediatric patients. Their ages during the screening for $\mathrm{CD}$ ranged from 10 months to 52 years. All of them were on a gluten-containing diet and none had been previously diagnosed with $\mathrm{CD}$. The serologic analysis for $\mathrm{CD}$ was performed at the Celiac Disease Investigation Laboratory from University of Brasilia School of Medicine, Brasília, DF, Brazil.

Immunoglobulin A ( $\operatorname{Ig} \mathrm{A})$ level was determined for the entire group by turbidimetric immunoquantification (Cobas Mira, Roche Diagnostic Systems, Berne, Switzerland). Levels lower than $5 \mathrm{mg} / \mathrm{dL}$ were considered abnormal.

Immunoglobulin A antiendomysium antibody assay (IgA-EMA) was also performed for all patients. Briefly, fixed cryostat sections from the distal portion of monkey esophagus (Inova Diagnostics, Inc. San Diego, CA, USA) were used as antigenic substrate and fluorescein-labeled goat antibody to human IgA was used as the second antibody. All sera were screened at a dilution of 1:5. The presence of a characteristic brilliant-green network pattern, visualized using a fluorescence microscope, was scored as positive. IgA-EMA positive assay was confirmed by the IgA class anti-tissue transglutaminase (IgA-tTG) antibody test using a commercial enzyme-linked immunosorbent assay (ELISA) kit (Inova Diagnostics, Inc. San Diego, CA, USA).

In addition, for patients with positive serologic testing, the presence of specific HLA alleles coded by DQA $1 * 0501$, DQB1*0201 and DRB1*04 was also determined by the polymerase chain reaction technique (PCR). Genomic DNA was extracted and purified from peripheral blood lymphocytes using a commercial kit according to the manufacturer's instructions (GFX Genomic Blood Purification KIT, Amersham Biosciences, USA) and was subjected to PCR with specific primers according to standard protocols ${ }^{(26)}$.

Small intestinal biopsy was proposed to patients showing positivity on serological testing and the jejunal biopsies were performed with a Watson pediatric capsule, near the ligament of Treitz. The biopsy specimens were blindly evaluated by a pathologist and a gastroenterologist and classified according to Marsh ${ }^{(18)}$ as type (O) normal, (I) infiltrative, (II) infiltrative hyperplastic, (III) flat destructive and (IV) atrophic hypoplastic. The diagnosis of CD was finally confirmed in subjects showing positivity on serological testing, presence of specific HLA heterodimer and jejunal biopsies specimens displaying Marsh grade I, II or III.

\section{RESULTS}

The mean age at diagnosis of TS was $5.5 \pm 4.4$ years and the mean age at screening for $C D$ was $17.0 \pm 9.3$ years, ranging from 10 months of age to 52years.

Among them, 24 presented the classical karyotype 45,X and the remaining presented different forms of mosaicism, structural aberrations and a marker chromosome (Table 1).

Two girls from the 56 females with Turner syndrome were IgA-EMA and IgA-tTG positive. One of them had diagnosis of TS at birth and diagnosis of CD at 7.5 years and the other had diagnosis of TS in the 6th month of life and diagnosis of $\mathrm{CD}$ in the 10th month. They had also HLA typing which showed that both of them presented the predisposing CD HLA-DQ2 alleles. They were offered to perform a small bowel biopsy for histological confirmation and their parents accepted to. The histology of the jejunal specimens from both girls was compatible with Marsh grade II.

Patient 1 had an uncommon early diagnosis of $\mathrm{CD}$ at 10 months of age, just 4 months after she started receiving gluten-containing diet. After 6 months of age, she progressively developed low weight and length gains, irritability and continuous flatulence.

Patient 2 presented a significant growth rate deceleration after 5 years of age (from $5.3 \mathrm{~cm} /$ year to $2.3 \mathrm{~cm} /$ year), coincidental with the period she started presenting recurrent abdominal pain and distention, diarrheic bouts, constant tiredness and weight loss.

TABLE 1. Frequency of the different karyotypes found among the 56 girls and women with TS studied in this survey

\begin{tabular}{|c|c|c|c|c|c|c|c|}
\hline Monossomy X & $\mathrm{n}$ & Mosaicism & $\mathrm{n}$ & Structural aberrations & $\mathrm{n}$ & Marker chromosome & $\mathrm{n}$ \\
\hline \multirow[t]{8}{*}{$45, \mathrm{X}$} & 24 & $45, \mathrm{X} / 46, \mathrm{XX}$ & 6 & $45, \mathrm{X} / 46, \mathrm{X}, \mathrm{r}(\mathrm{X})$ & 5 & $45, \mathrm{X} / 46, \mathrm{X},+\mathrm{mar}$ & 6 \\
\hline & & $45, \mathrm{X} / 47, \mathrm{XXX}$ & 4 & $45, \mathrm{X} / 46, \mathrm{X}, \mathrm{i}(\mathrm{X})(\mathrm{q} 10)$ & 4 & & \\
\hline & & $45, \mathrm{X} / 46, \mathrm{XY}$ & 1 & $45, \mathrm{X} / 46, \mathrm{X}, \mathrm{i}(\mathrm{Y})(\mathrm{q} 10)$ & 1 & & \\
\hline & & $45, \mathrm{X} / 47, \mathrm{XXX} / 46, \mathrm{XX}$ & 1 & 45,X/46, $\mathrm{Xr}(\mathrm{Y})$ & 1 & & \\
\hline & & & & $46, \mathrm{XX}, \mathrm{del}(\mathrm{X})$ & 1 & & \\
\hline & & & & $45, \mathrm{X} / 46, \mathrm{X}, \operatorname{inv}(\mathrm{X})(\mathrm{q} 13 ; \mathrm{q} ; 27)$ & 1 & & \\
\hline & & & & $44, \mathrm{X}, \operatorname{der}(13 ; 14)(\mathrm{q} 10 ; \mathrm{q} 10) / 45, \mathrm{X}, \mathrm{i}(\mathrm{X})$ & 1 & & \\
\hline & & & & $(\mathrm{q} 10), \operatorname{der}(13 ; 14)(\mathrm{q} 10 ; \mathrm{q} 10)$ & & & \\
\hline Total: 56 & 24 & & 12 & & 14 & & 6 \\
\hline
\end{tabular}


Dias MCS, Castro LCG, Gandolfi L, Almeida RC, Córdoba MS, Pratesi R. Screening for celiac disease among patients with Turner syndrome in Brasília, DF, Midwest region of Brazil

So, in the present study, it was found that the prevalence of biopsy-proven CD among this group of females with TS was 2 in 56 subjects (3.6\%). Data from these 2 girls are shown in Table 2. None of the 56 patients displayed abnormal levels of IgA.

TABLE 2. Citogenetic, immunological and histopathology of jejunal biopsy results from the two girls presenting Turner syndrome and celiac disease

\begin{tabular}{lcc}
\hline Patient & 1 & 2 \\
\hline Age at TS diagnosis & 6 months & at birth \\
Age at CD diagnosis & 10 months & 7.5 years \\
Karyotype & $45, \mathrm{X} / 46, \mathrm{XX}$ & $45, \mathrm{X}$ \\
IgA-EMA & positive & (SRY negative, DYZ3 negative) \\
IgA-tTG* & $41.8 \mathrm{U} / \mathrm{mL}$ & $86.4 \mathrm{U} / \mathrm{mL}$ \\
HLA & DQ2 + DRB4- & DQ2 + DRB4- \\
Jejunal biopsy & Marsh II & Marsh II \\
\hline
\end{tabular}

IgA-tTG cutoff values: $<20 \mathrm{U} / \mathrm{mL}=$ negative; $20-30 \mathrm{U} / \mathrm{mL}=$ borderline; $>30 \mathrm{U} / \mathrm{mL}=$ positive

TS = Turner syndrome; $\mathrm{CD}$ = celiac disease

\section{DISCUSSION}

Although the TS classic described karyotype is $45, \mathrm{X}$, it is found only in near half of these females, the remaining displaying mosaicism for 45,X (with one or more additional cell lineages, including sometimes the entire or just part of chromosome $\mathrm{Y}$ ) or isochromosome of the long arm of one $\mathrm{X}(46, \mathrm{X}, \mathrm{i}(\mathrm{Xq}))^{(1,31)}$. Among the females participating in this study, it was found a similar frequency of the different karyotypes.

The results of this survey reinforce the existence of an increased prevalence of CD among females with TS. The prevalence of $\mathrm{CD}$ observed in this group of females with TS (3.6\%) was lower than the prevalence of $6.4 \%$ reported by Bonamico et al. ${ }^{(4)}$ but similar to the prevalence found in other studies, varying from 2.2 to $5.0^{(8,12,13)}$. Some of those studies have shown that part of the diagnosed patients were asymptomatic or presented atypical forms of $\mathrm{CD}$.

Several CD screening studies carried out during the last decade in Brazil have shown a prevalence of $\mathrm{CD}$ similar to that found in European countries, varying from 1:681 (0,14\%) to $1: 214(0.46 \%)$ in presumably healthy blood donors ${ }^{(11,20,23,}$ ${ }^{24,26)}$ and from $0.34 \%$ to $0.84 \%$ in the general population ${ }^{(13,25)}$.

In a previous survey performed with 2,629 girls and adult women at the same geographic area of this current study, it was found 8 females presenting biopsy-proven $\mathrm{CD}$, corresponding to $0.34 \%$ prevalence ${ }^{(25)}$. The prevalence of biopsy-proven CD found in this current study was 3.6\%, 10 times higher.

$\mathrm{CD}$ has been recognized as polymorphic disorder. Some studies have shown that short stature and/or low growth rate can be the primary or even the only manifestations of $\mathrm{CD}^{3}$, ${ }^{6}$ ), the same occurring in non classical TS presentation ${ }^{(19,30)}$. This observation strengthens the rationale for screening for both $\mathrm{CD}$ and TS when investigating girls with short stature and/or failure to thrive.

In one of the girls with $\mathrm{CD}$ from this study, the clinical manifestations appeared only after she was 5 years old, though she has been on gluten containing diet since her 1st year of life. This finding associated with previous articles reporting diagnosis of $\mathrm{CD}$ in asymptomatic adult women with $\mathrm{TS}^{(10)}$ and asymptomatic girls with $\mathrm{TS}^{(3)}$ demonstrate the relevance of retesting, on a periodically basis, females with TS presenting negative testing for $\mathrm{CD}$, regardless of symptoms.

In conclusion, the finding of a 3.6\% prevalence of biopsy proven CD patients among 56 females with TS in this Brazilian sample gives additional support that, as reported in other countries, an association between these two disorders also exists in our population. This result reinforces that screening for CD must be part of the routine follow-up of girls and women with TS, once they represent a high risk group for developing the disease.

\section{ACKNOWLEDGMENT}

This study was supported by the research funds of the Celiac Disease Investigation Laboratory, Department of Pediatrics, University of Brasilia School of Medicine, Brasilia, DF, Brazil..

Dias MCS, Castro LCG, Gandolfi L, Almeida RC, Córdoba MS, Pratesi R. Triagem para doença celíaca em pacientes com síndrome de Turner em Brasília, DF, região centro-oeste do Brasil. Arq Gastroenterol. 2010;47(3):246-9.

RESUMO - Contexto - Alguns estudos têm demonstrado maior prevalência de doença celíaca entre mulheres com síndrome de Turner, quando comparadas com a população geral. Entretanto, não há registro na literatura desta investigação em pacientes brasileiras. Objetivo - Avaliar a prevalência de doença celíaca entre um grupo de pacientes brasileiras com síndrome de Turner. Métodos - Cinquenta e seis pacientes com síndrome de Turner recebendo dieta contendo glúten foram triadas para doença celíaca, utilizando-se ensaios sorológicos com anticorpos imunoglobulina A antiendomísio (IgA-EMA) e imunoglobulina A antitranslgutaminase tecidual (IgA-tTG). Adicionalmente, elas foram genotipadas para os alelos predisponentes para doença celíaca de antígenos leucocitários humanos (doença celíaca-HLA). Às pacientes que mostraram positividade no teste sorológico, propôsse a realização de biopsia do intestino delgado para confirmação histológica. Resultados - A idade média ao diagnóstico de síndrome de Turner foi 5,5 \pm 4,4 anos; idade média durante a triagem da doença celíaca foi 17,0 \pm 9,3 anos (abrangendo dos 10 meses de idade aos 52 anos). Duas meninas foram positivas para IgA-EMA e IgA-tTG, apresentaram os alelos predisponentes para doença celíaca HLA-DQ2 e tiveram o diagnóstico de doença celíaca confirmado por biopsia jejunal. Conclusão - A prevalência de 3,6\% de doença celíaca confirmada por biopsia neste grupo de pacientes com síndrome de Turner, foi 10 vezes maior que aquela encontrada entre mulheres da população geral da mesma área geográfica. Este resultado contribui para corroborar a associação entre estas duas doenças e reforça que meninas e mulheres com síndrome de Turner constituem uma população de risco aumentado para desenvolver doença celíaca.

DESCRITORES - Triagem. Doença celíaca. Síndrome de Turner. Autoimunidade. Anticorpos. 


\section{REFERENCES}

1. Baena N, De Vigan C, Cariati E, Clementi M, Stoll C, Caballín MR, Guitart M Turner syndrome: evaluation of prenatal diagnosis in 19 European registries. Am J Med Genet A. 2004;129A:16-20.

2. Baxter L, Bryant J, Cave CB, Milne R. Recombinant growth hormone for children and adolescents with Turner syndrome. Cochrane Database Syst Rev. 2007;Jan 24:CD003887.

3. Bonamico M, Scirè G, Mariani P, Pasquino AM, Triglione P, Scaccia S, Ballati G Boscherini B. Short stature as the primary manifestation of monosymptomatic celiac disease. J Pediatr Gastroenterol Nutr. 1992;14:12-6.

4. Bonamico M, Pasquino AM, Mariani P, Danesi HM, Culasso F, Mazzanti L, Petri A, Bona G; Italian Society Of Pediatric Gastroenterology Hepatology (SIGEP); Italian Study Group for Turner Syndrom (ISGTS). Prevalence and clinical picture of celiac disease in Turner syndrome. J Clin Endocrinol Metab. 2002;87:5495-8.

5. Bondy CA. Turner Syndrome 2008. Horm Res. 2009;71:52-6.

6. Cacciari E, Salardi S, Lazzari R, Cicognani A, Collina A, Pirazzoli P, Tassoni P, Biasco G, Corazza GR, Cassio A. Short stature and celiac disease: a relationship to consider even in patients with no gastrointestinal tract symptoms. J Pediatr. 1983;103:708-11.

7. Catassi C, Fornaroli F, Fasano A. Celiac disease: from basic immunology to bedside practice. Clin Appl Immunol Rev. 2002;3:61-71.

8. Crovella S, Brandao L, Guimaraes R, Filho JL, Arraes LC, Ventura A, Not T Speeding up coeliac disease diagnosis in developing countries. Dig Liver Dis 2007;39:900-2.

9. Durusu M, Gürlek A, Simsek H, Balaban Y, Tatar G. Coincidence or casuality: celiac and Crohn diseases in a case of Turner syndrome. Am J Med Sci. 2005;329:214-6.

10. Frost AR, Band MM, Conway GS. Serological screening for coeliac disease in adults with Turner's syndrome: prevalence and clinical significance of endomysium antibody positivity. Eur J Endocrinol. 2009;160:675-9.

11. Gandolfi L, Pratesi R, Cordoba JC, Tauil PL, Gasparin M, Catassi C. Prevalence of celiac disease among blood donors in Brazil. Am J Gastroenterol. 2000;95:689-92.

12. Gillett PM, Gillett HR, Israel DM, Metzger DL, Stewart L, Chanoine JP, Freeman HJ. Increased prevalence of celiac disease in girls with Turner syndrome detected using antibodies to endomysium and tissue transglutaminase. Can J Gastroenterol. 2000;14:915-8

13. Ivarsson SA, Carlsson A, Bredberg A, Alm J, Aronsson S, Gustafsson J, Hagenäs L, Häger A, Krisdtöm B, Marcus C, Moëll C, Nilsson KO, Tuvemo T, Westphal O, Albertsson-Wikland K, Aman J. Prevalence of coeliac disease in Turner syndrome. Acta paediatr. 1999;88:933-6.

14. Kagnoff MF. Overview and pathogenesis of celiac disease. Gastroenterology 2005; $128:$ s $10-8$

15. Livadas S, Xekouki P, Fouka F, Kanaka-Gantenbein C, Kaloumenou I, Mavrou A, Constantinidou N, Dacou-Voutetakis C. Prevalence of thyroid dysfunction in Turner's syndrome: a long-term follow-up study and brief literature review. Thyroid. 2005;15:1061-6.

16. Louka AS, Sollid LM. HLA in coeliac disease: unravelling the complex genetics of a complex disorder. Tissue Antigens. 2003;61:105-17.

17. Manzione NC, Kram M, Kram E, Das KM. Turner's syndrome and inflammatory bowel disease: a case report with immunologic studies. Am J Gastroenterol. 1988;83:1294-7.
18. Marsh M. Gluten, major histocompatibility complex, and the small intestine. A molecular and immunobiologic approach the spectrum of gluten sensitivity ('celiac sprue'). Gastroenterology. 1992;102:330-54.

19. Massa GG, Vanderschueren-Lodeweyekx M. Age and height at diagnosis in Turner syndrome: influence of parental height. Pediatrics. 1991;88:1148-52.

20. Melo SB, Fernandes MI, Peres LC, Troncon LE, Galvao LC. Prevalence and demographic characteristics of celiac disease among blood donors in Ribeirão Preto, State of São Paulo, Brazil. Dig Dis Sci. 2006;51:1020-5.

21. Mortensen KH, Cleemann L, Hjerrild BE, Nexo E, Locht H, Jeppesen EM, Gravholt $\mathrm{CH}$. Increased prevalence of autoimmunity in Turner syndrome - influence of age. Clin Exp Immunol. 2009;156:205-10.

22. Nenna R, Mora B, Megiorni F, Mazzilli MC, Magliocca FM, Tiberti C, Bonamico M. HLA-DQB $1 * 02$ dose effect on RIA anti-tissue transglutaminase autoantibody levels and clinicopathological expressivity of celiac disease. J Pediatr Gastroentero Nutr. 2008;47:288-92.

23. Oliveira RP, Sdepanian VL, Barreto JA, Cortez AJ, Carvalho FO, Bordin JO, de Camargo Soares MA, da Silva Patrício FR, Kawakami E, de Morais MB, FagundesNeto U. High prevalence of celiac disease in Brazilian blood donor volunteers based on screening by IgA antitissue transglutaminase. Eur J Gastroenterol Hepatol. 2007;19:43-9.

24. Pereira MA, Ortiz-Agostinho CL, Nishitokukado I, Sato MN, Damião AO, Alencar ML, Abrantes-Lemos CP, Cançado EL, de Brito T, Ioshii SO, Valarini SB, Sipahi AM. Prevalence of celiac disease in an urban area of Brazil with predominantly European ancestry. World J Gastroenterol. 2006;12:6546-50.

25. Pratesi R, Gandolfi L, Garcia SG, Modelli IC, Almeida PL, Bocca AL, Catass C. Prevalence of coeliac disease: unexplained age-related variation in the same population. Scand J Gastroenterol. 2003;38:747-50.

26. Sacchetti L, Sarrantonio C, Pastore L, Carlino V, Calcagno G, Ferrajolo A, Salvatore F. Rapid identification of HLA DQA $1 * 0501$, DQB1*0201 and DRB1*04 alleles in celiac disease by a PCR-based methodology. Clin Chem. 1997;43:2204-6.

27. Setty M, Hormaza L, Guandalini S. Celiac disease: risk assessment, diagnosis, and monitoring. Mol Diagn Ther. 2008;12:289-98.

28. Sollid LM. Molecular basis of celiac disease. Annu Rev Immunol. 2000;18:53-81

29. Stephure DK; Canadian Growth Hormone Advisory Committee. Impact of growth hormone supplementation on adult height in turner syndrome: results of the Canadian randomized controlled trial. J Clin Endocrinol Metab. 2005;90:3360-6.

30. Stochholm K, Juul S, Juel K, Naeraa RW, Hojbjerg, Gravholt C. Prevalence, incidence, diagnostic delay, and mortality in Turner syndrome. J Clin Endocrino Metab. 2006;91:3897-3902

31. Sybert V, McCauley E. Turner's syndrome. N Engl J Med. 2004;351:1227-38.

32. Turner HH. A syndrome of infantilism, congenital webbed neck and cubitus valgus. Endocrinology. 1938;23:566-74.

33. Wihlborg CE, Babyn PS, Schneider R. The association between Turner's syndrome and juvenile rheumatoid arthritis. Pediatr Radiol. 1999;29:676-81.

34. Zulian F, Schumacher HR, Calore A, Goldsmith DP, Athreya BH. Juvenile arthritis in Turner's syndrome: a multicenter study. Clin Exp Rheumatol. 1998:16:489-94.

Received 24/8/2009. Accepted 18/12/2009. 